\title{
DINAMICA COMPUȘILOR AZOTULUI MINERAL ÎN APELE RÂULUI PRUT
}

\section{Petru Ciorba}

\author{
Institutul de Zoologie, e-mail: ciorba.petru1992@gmail.com
}

https://doi.org/10.53937/9789975151979.04

\begin{abstract}
Rezumat
În articolul dat sunt prezente rezultatele studierii conținutului compușilor azotului mineral (ioni de amoniu, nitriți și nitrați) în anul 2020 din râul Prut sectorul Braniște-Giurgiulești. În cadrul studiului este examinată dinamica sezonieră a acestor parametri în perioada de iarnă-primăvară-vară-toamna. Diapazonul concentrației ionilor de amoniu în apele r. Prut variază de la 0,002 până la 0,26 mgN/l, ionilor de nitriți - de la 0,002 până la 0,02 mgN/l și a nitraților - de la 0,002 până la 0,73 mgN/l, maximele fiind mai scăzute de cele din anii 2009-2010, și mult mai mici decât cele din anii' 80-90 ai secolului trecut.
\end{abstract}

Cuvinte-cheie: compuși ai azotului, ioni de amoniu, nitriți, nitrați, substanțe nutritive.

\section{INTRODUCERE}

Compușii azotului mineral reprezintă o parte din substanțele nutritive sau biogene în apă ale ecosistemelor acvatice. Conținutul ionilor de nitrați, nitriți și amoniu au devenit unii din cei mai principali indicatori pe scară largă în evaluarea calității apelor și stării ecologice a ecosistemelor acvatice [5]. Compușii azotului mineral deseori sunt factorii determinanți în dezvoltarea organismelor acvatice, în intensitatea proceselor producțional-destrucționale ale producenților primari de hidrobionți și a diferitor grupe de microorganisme acvatice și a nivelului de troficitate ale ecosistemelor. Dinamica substanțelor nutritive, ale azotului și fosforului, este determinatoare ale proceselor biochimice și biologice în ecosistemul acvatic.

La rîndul său, cationii de amoniu $\left(\mathrm{NH}_{4}^{+}\right)$, și anioni de nitriți $\left(\mathrm{NO}_{2}^{-}\right)$și nitrați $\left(\mathrm{NO}_{3}^{-}\right)$în ecosistemele acvatice sunt într-o dependență reciprocă și pot trece dintr-o formă în alta, în dependență de factorii fizico-chimici (a valorilor temperaturii, $\mathrm{pH}$-lui, conducțivității, regimului gazos) cât și de dezvoltarea hidrobionților planctonici și bentonici, în deosebi ale algelor și bacteriilor [1].

Compușii azotului mineral sunt substanțe nutritive sau biogene, însă în condițiile impactului

\begin{abstract}
In this article the results on the content of mineral nitrogen compounds (ammonium ions, nitrites and nitrates) during 2020 year in the Prut River Braniște - Giurgiulesti sector are presented. In the study is examinated the seasonal dynamics of these parameters in the winter - spring - summer autumn period. The range of ammonium ions in the waters of the Prut River varies from 0.002 to 0.26 $\mathrm{mgN} / \mathrm{L}$, of nitrite - from 0.002 to $0.02 \mathrm{mgN} / \mathrm{L}$ and of nitrates - from 0.002 to $0.73 \mathrm{mgN} / \mathrm{L}$, the maximums being lower than in 2009-2010, and much lower than in the 80s-90s of the last century.
\end{abstract}

Keywords: Nitrogen compounds, nitrates, nitrites, ammonia, biogenic substances.

uman (deversarea apelor reziduale, utilizarea intensivă a îngrășămintelor în acvacultură ș.a.) pot atinge concentrații mari, devenind - substanțe poluante și toxice [4].

Ca urmare a investigațiilor acestor compuși chimici în corpurile de apă este posibilă estimarea schimbărilor mediului acvatic, aprecierea intensității migrației și circuitului substanțelor chimice, evaluarea impactului lor asupra hidrobionților, stabilirea legităților funcționării hidrobiocenozelor și prevenirea consecințelor nefaste asupra ecosistemelor.

\section{MATERIALE ȘI METODE}

Probele de apă au fost colectate din r. Prut în punctele Braniște, Leușeni, Cahul, Cîșlița-Prut și Giurgiulești, pe parcursul anului 2020 în lunile februarie, mai, iunie (perioada de inundație), iulie, octombrie

Conținutul ionilor de amoniu a fost determinat prin metoda spectrofotometrică [2] Principiul metodei constă în reacția ionilor de amoniu, în mediu bazic, cu tetraiodomercuratul de potasiu (K2[HgI4]) în rezultatul căruea se formează un complex (iodura de oximercuramoniu) de culoare 
galben-brun. Intensitatea culorii este proporțională cu conținutul ionilor de amoniu din proba de analizat. Apa pentru analiză în volum de $50 \mathrm{ml}$ se ia în balonul cotat $(50 \mathrm{ml})$, se adaugă $1 \mathrm{ml}$ sare Seignette și se amestecă bine. Apoi se adaugă $1 \mathrm{ml}$ reactivul lui Nessler. Soluția obținută se amestecă bine și se lasă timp de 7-10 min. pentru dezvoltarea culorii. După 10 min. se măsoară densitatea optică a soluției în cuve de $10 \mathrm{~mm}$, la $\lambda=400 \mathrm{~nm}$ în raport cu apa analizată.

Conținutul nitriților a fost determinat prin metoda spectrofotometrică [2]. Principiul metodei date constă în formarea compusului diazonic de culoare de la roz până la roșu, intensitatea crescând odată cu creșterea concentrației. Se ia $50 \mathrm{ml}$ de apă în balon (50 ml), se adaugă $0,1 \mathrm{~g}$ reactiv Griess, se amestecă bine și se lasă timp de 40 min. pentru dezvoltarea culorii. După 40 min. se măsoară densitatea optică la spectrofotometru ( $\lambda=540 \mathrm{~nm}$ ) în cuve de $10 \mathrm{~mm}$ în raport cu apa de analizat.

Conținutul nitraților a fost determinat prin metoda spectrofotometrică [2]. Metoda constă în determinarea intensității culorii nitroderivaților care se formează prin reacția chimică între acidul salicilic cu nitrații din apă în mediu acid. Intensitatea culorii este direct proporțională cu conținutul nitraților. Tehnica de laborator: într-o serie de pahare $(50 \mathrm{ml})$ se iau câte $10 \mathrm{ml}$ de probă de apă supuse analizei în care se adaugă $1 \mathrm{ml}$ salicilat de sodiu (proaspăt pregătit). Paharele cu probe se pun la evaporare și se țin până la uscarea probei. După răcirea pînă la temperatura camerei, în fiecare pahar se adaugă $1 \mathrm{ml}$ de acid sulfuric concentrat $(\rho=1,84 \mathrm{~g} / \mathrm{l})$, umezind bine pereții paharului și se lasă timp de 10-15 min. Între timp, prin mișcări de rotaţii lente ale paharului, se „prelinge” bine acidul pe pereții paharului pentru o dizolvare totală. După 15 min., proba cantitativ, cu utilizarea apei distilată, se trece în baloane cotate de $50 \mathrm{ml}$. În fiecare colbă se adaugă $7 \mathrm{ml} \mathrm{NaOH}(10 \mathrm{~N})$ și se aduce cu apă distilată până la cotă. Se pune capacul și colba se amestecă bine. După 10 min. se măsoară densitatea optică a soluției în cuve de $10 \mathrm{~mm}$ la $\lambda=400 \mathrm{~nm}$ în raport cu apa analizată. În cazul apelor cu conținut mare de nitrați, inițial se va lua 1 $\mathrm{ml}$ de probă de analizat.

Pentru măsurarea densităților optice a fost utilizat spectrofotometrul UV-VIS SPECORD ${ }^{\circledR} 210$ Plus (Analytik Jena, Germania).

\section{REZULTATE ȘI DISCUȚII}

Rezultatele obținute demonstrează că concentrația ionilor de amoniu a fost maximă iarna pe porțiunea r. Prut la Braniște, aceasta putem argumenta prin influiența apelor din acumularea Costești- Stînca, care apoi pe cursul r. Prut a scăzut de 5 ori. În lunile mai, și octombrie se observă o creștere neesențială a concentrației ionilor de amoniu în sectorul inferior la Cîșlița-Prut-Giurgiulești însă dinamica sezonieră esle slab pronunțată (Figura 1).

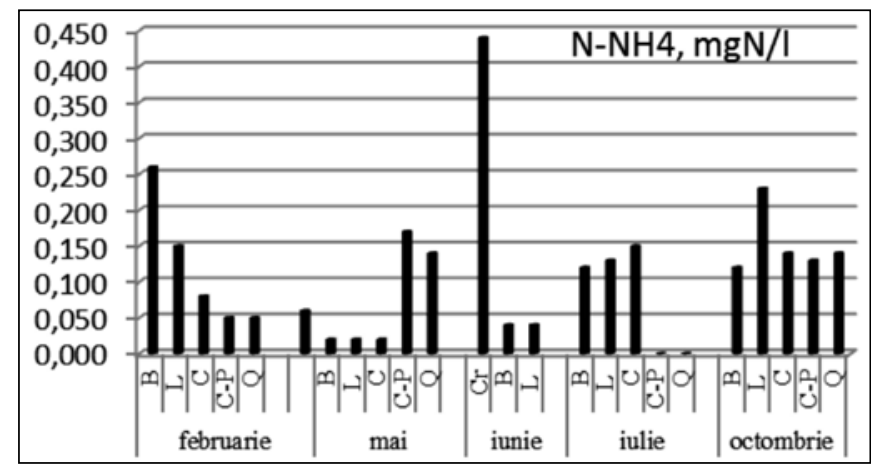

Fig. 1. Dinamica concentrației cationilor de amoniu $\left(\mathrm{N}-\mathrm{NH}_{4}^{+}\right)$în apele r. Prut în mgN/l

(Cr-Criva, B-Branişte, L-Leuşeni, C-Cahul, Cp-Cîşliţa-Prut, Q-Giurgiuleşti)

Conform Regulamentului cu privire la cerințele de calitate a mediului pentru apele de suprafață [3] apele r. Prut investigate, după conținutul ionilor de amoniu, se referă la clasa I de calitate (apă foarte bună) și numai in în februarie - la Braniște, și în octombrie - la Leușeni- la clasa II de calitate (apă bună).

În perioada de inundație la intrarea apei pe teritoriul R. Moldova (Criva) concentrația ionilor de amoniu a atins valoarea caracteristică pentru apele moderat poluate - clasa III de calitate.

Concentrațiile ionilor de amoniu în anul curent sunt vizibil mai mici de cele din anii 2009-2011 și mult mai mici cu cei din anii' $80-90$ ai secolului trecut [6].

Nitriții, fiind treapta intermediară în procesul de nitrificare de la ioni de amoniu până la nitrați, în apele r. Prut se află în cantități mici ce nu depăsesc $0,02 \mathrm{mgN} / 1$ și numai în perioada de inundație în iunie a atins valoarea de $0,03 \mathrm{mgN} / \mathrm{l}$ (Figura 2). Nitriții sunt indicatori de poluare proaspătă alohtonă. Conținutul lor în apele r. Prut corespund ecosistemelor cu apa claselor I-II de calitate.

Concentrațile maxime ale nitraților au fost în perioada de iarnă-primăvară, fiind majorate, în timpul anului, la Cahul (Figura 3). 


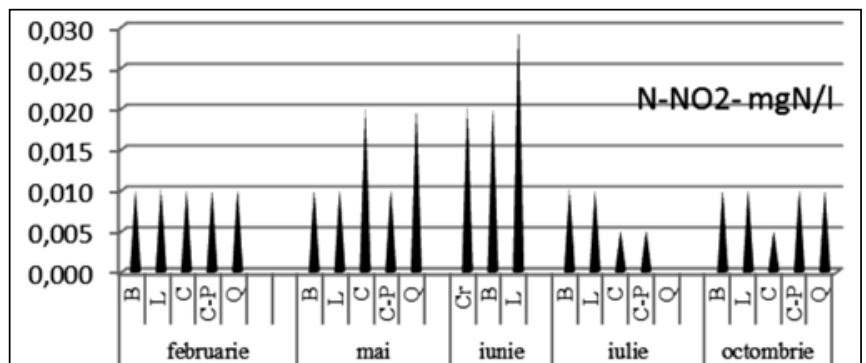

Fig. 2. Dinamica concentrației anionilor de nitriți $\left(\mathrm{N}-\mathrm{NO}_{2}{ }^{-}\right)$în apele r. Prut în $\mathrm{mg} \mathrm{N} / \mathrm{l}$

(Cr-Criva ,B-Branişte, L-Leuşeni, C-Cahul, C-P-Cîşliţa-Prut, Q-Giurgiuleşti)

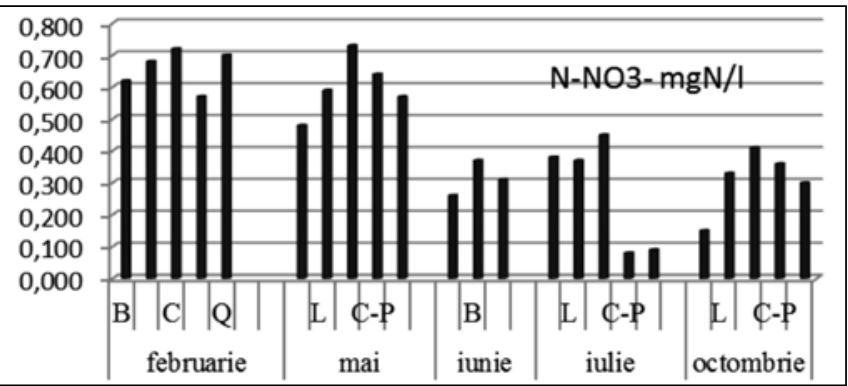

Fig. 3. Dinamica concentrației anionilor de nitrați $\left(\mathrm{N}-\mathrm{NO}_{3}{ }^{-}\right)$în apele r. Prut în mg $\mathrm{N} / \mathrm{l}$

(Cr- Criva ,B-Branişte, L-Leuşeni, C-Cahul, Cp-Cîşliţa-Prut, Q-Giurgiuleşti)

Conținutul nitraților nu depășește 0,75 mgN/l, ce este vizibil mai mic decât valorile acestor substanțe stabilite în anii 2009-2011 și mult mai mici în comparație cu valorile din anii' 80-90 ai secolului trecut [6].

Conform cerintelor de calitate pentru apele de suprafață, concentrațiile ionilor de nitrați în apele r. Prut corespund clasei I de calitate - apă foarte bună.

Conținutul azotului de nitrat, în majoritatea cazurilor, predomină asupra azotului de amoniu și azotului de nitriți și, numai din cauza creșterii concentratiei azotului de amoniu în timpul inundatiilor din 2020 la Criva, cota parte a azotului nitrat a fost mai mică de ceea a azotului de amoniu (Figura 4).

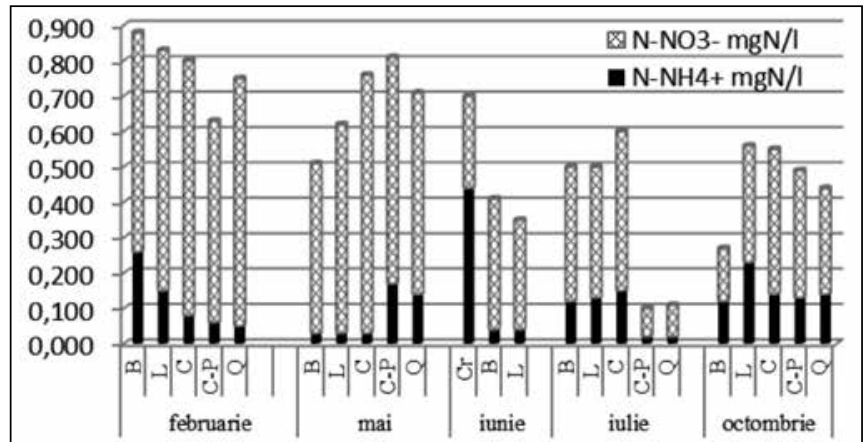

Fig. 4. Dinamica raportului cationilor de amoniu cu anionii de nitrați în r. Prut

(Cr- Criva ,B-Branişte, L-Leuşeni, C-Cahul, Cp-Cîşliţa-Prut, Q-Giurgiuleşti)

\section{CONCLUZII}

Astfel, apele r. Prut, de cele mai multe ori, au fost satisfăcătoare pentru dezvoltarea hidrobionților.

Dinamica concentrațiilor ionilor de amoniu, nitriți și nitrați pe parcursul anului 2020 în r. Prut, în mare măsură, a reprezentat procesele caracteristice apelor de suprafață din regiunea dată.

Conţinutul compușilor minerali ai azotului (ionii de amoniu, nitriți și nitrați) atribuie apele investigate la cele de clasele I-II de calitate (ape foarte bune și bune), care pot fi utilizate pentru potabilizare și acvacultură.

Cercetările au fost realizate în cadrul proiectului 20.80009.7007.06 "Determinarea schimbărilor mediului acvatic, evaluarea migrației și impactului poluanților, stabilirea legităților funcționării hidrobiocenozelor și prevenirea consecințelor nefaste asupra ecosistemelor" - AQUABIO (Programul de Stat 2020-2023).

Autorul este recunoscător dnei Bagrin Nina, doctor în științe biologice, cercetător științific coordonator, pentru suportul metodologic în realizarea investigațiilor.

\section{REFERINȚE}

1. GAZAEV H. M., JINJAKOVA L. Z., ATABIEVA F. A., ITTIEV A. B. Existential change of the content of inorganic compounds of nitrogen in waters $\mathrm{r}$. Cherek from the source to the mouth. Izvestia, or. Nalicik, 2014, 164 pag., pag. 134-138.

2. Monitoringul calității apei și evaluarea stării ecologice a ecosistemelor acvatice : Îndrumar metodic/Acad. de Științe a Moldovei, Inst. de Zoologie, Univ. Acad. de Științe a Moldovei. - Chișinău :S. n., 2015, Tipogr. „Elan Poligraf ”, 84 p.

3. Regulamentul cu privire la cerinţele de calitate a mediului pentru apele de suprafaţă . Hotărîrea Guvernului nr. 890 din 22.11.2013 în Monitorul Oficial Nr. 262-267 art Nr : 1006

4. ROJDESTVENSKAIA T.A., PUZANOV A.V., GORBACEV I.V. Нитраты и нитриты в поверхностных и подзвемных водах Алтая, Мир Науки, Культуры, Образования. No2(9), 2008.

5. STOROZHENKO E.A., KORNILOV A.G., MARYNYCH S.N. Spatial Dynamics of Nitrogen Pollution of Small Rivers of Belgorod, Belgorod State University Scientific Bulletin. Natural sciences series, 2018, V. 42, No. 3, p. 427-434.

6. ZUBCOV, E.; UNGUREANU, L.; TODERAS,, I.; BILETCHI, L.; BAGRIN, N. Hydrobiocenosis State of the Prut River in the Sculeni - Giurgulesti Sector. Water Science and Tehnology Library. Management of Water Quality in Moldova, Springer, 2014, Volume 69, pp.97-156 